\title{
Investigation of Groundwater Prospecting Zones of the Giri River Catchment of the Himachal Pradesh and Its Quality Suitability for Human Consumption
}

\author{
Dissanayake DMDOK \\ Department of Earth Resources Engineering, Faculty of Engineering, University of Moratuwa, Katubedda, Sri Lanka
}

Email address:

kithsiridissanayake@yahoo.com

\section{To cite this article:}

Dissanayake DMDOK, Investigation of Groundwater Prospecting Zones of the Giri River Catchment of the Himachal Pradesh and Its Quality Suitability for Human Consumption. Journal of Water Resources and Ocean Science, Vol. 10, No. 4, 2021, pp. 78-91.

doi: $10.11648 /$ j.wros.20211004.12

Received: August 19, 2021; Accepted: September 6, 2021; Published: September 23, 2021

\begin{abstract}
In this research study, an integrated remote sensing and GIS methodology is developed and tested for the evaluation of groundwater resources of the GiRi river catchment area that exceeds 2,684 $\mathrm{km}^{2}$ in the districts of Sirmur, Solan and Shimla of Himachal Pradesh. IRS-LISS-III and Landsat 7 data and other datasets, e.g. Existing maps, topographic and field survey data were used to extract hydrogeomorphic features to develop thematic maps such as geology, geomorphology, rainfall, slope, aspect, drainage density and lineament. These thematic layers were integrated into a GIS environment and the criteria for the mapping of potential groundwater zones and the adequacy of groundwater quality for human consumption were identified. The weighted index overlap analysis was followed to delineate potential groundwater areas and the weights of the above criteria were determined by the analytical hierarchy process method and this study confirmed that the specific hydrological and meteorological conditions which affect groundwater prospecting and their weight can change depending on the condition of each region. Piedmont area between the Giri and Bata rivers, intensively cultivated and have excellent underground potential. Based on the final hydrogeomorphic map, 3.6\% representing the valley fields deposits offer a very high groundwater potential. Dissected hills of granite rocks, metamorphic rocks, limestones and sandstones distributed throughout the remaining area, accounted for $3.2 \%, 52.24 \%, 33.92 \%$ and $7.0 \%$ respectively, a very low, low, moderate and very high groundwater potential respectively. The results of the water analysis indicated a high hardness value (>300 mg / l) throughout the region, but it is below the permitted limit $(<600 \mathrm{mg} / \mathrm{l})$. It has been noted that the iron $(\mathrm{Fe})$ content is exceeded in some areas beyond the permitted limit $(0.3 \mathrm{mg} / 1)$ and this may be due to various reasons probably due to the iron casing of the tube well and or aquifers may have been contaminated by ion-rich rocks and the soil of the region.
\end{abstract}

Keywords: Groundwater, Geology, Geomorphology, Structure, Slope, Aspect, Drainage Density, Rain Fall

\section{Introduction}

\subsection{Overview}

Groundwater is a precious resource of limited extent. Appropriate assessment is necessary to ensure prudent use of groundwater. Any groundwater development project requires a large volume of multidisciplinary data from various sources. Remote sensing integrated with Global Positioning System in a GIS environment can provide the appropriate platform for convergent analysis of various datasets for decision making in groundwater management and planning [1]. Recent advances in integrated remote sensing, GIS and GPS will help provide and process large amounts of data simultaneously in a time- and cost-efficient manner [2]. Remote sensing and GIS are playing an increasingly important role in hydrology and the development of water resources. Remote sensing provides multispectral, multitemporal and multisensory data of the earth's surface. A major benefit of using remote sensing data for hydrological studies and monitoring is the ability to generate information over a specific time frame, which is critical for successful analysis, prediction and validation. However, the use of remote sensing technology includes a large part of spatial 
data management and requires an efficient system to manage this data [3].

GIS technology offers valid alternatives for effective and efficient management of large and complex databases [4]. Information from satellites is becoming increasingly important for environmental research. An important part of this information concerns the water element, vital for man, its phases and peculiarities.

In general, water resources in India are unevenly distributed in terms of time and space. The peculiarities of the monsoons and the different physiographic conditions lead to an uneven distribution of water. Over the years, population growth, urbanization and the expansion of agriculture have accentuated the situation. The consequence of the unscientific use of groundwater is heading towards a state of water scarcity. Parts of the country are already facing a severe water crisis [5]. Although it is a very important part of the country's growth, the analysis of its water resources has been sketchy.

Remote sensing is an extremely valuable tool for mapping land use, land cover categories and geomorphological features necessary for the planning and management of water resources [6]. The importance and use of remote sensing data in hydrogeological application is based on the fact that the image helps the investigator to localize the morphological and structural features that can influence the groundwater flow [7].

Appropriate compilation of fracture, geology, geomorphology, slope, aspect, drainage density result in locating ground water prospect zones. The geographical mapping plays an important role in exploration, since different rock units and structures govern the occurrence the movement of ground water and the surface drainage that develop on them. Land forms and relief also play in affecting run off recharge and water movement. Rock formation can be identified on aerial and satellite data with the aid of imperative recognition elements, and related land form studies [8].

Crystalline hard rock hold groundwater depends on the depth and extend of weathers materials overlying unweathered bed rock (variable pediment zones), and the size, nature, intensity, orientation and inter-connection of joints, fracture, fissure and faults in these rocks. Study of fractures, their pattern, density, frequency, nature and orientation, extension into covered areas using air photo and satellite picture analysis are especially useful in targeting ground water in hard rock terrains. Open fracture zones are good yields of groundwater from well located along them. Geomorphic mapping of outcrop and weathered zones, as well as delineating of fault-fractures systems in hard rock areas can be greatly aided by image interpretation. Major faults and fracture zones are known to yield good quantities of ground water in such areas. Deeper weathered pediments are also good [9]. Therefore, hydrogeological importance of several factors related to groundwater occurrence, can be used as a working reference for future groundwater-development programs [10].

\subsection{Previous Work}

Preliminary geological mapping work of the western Kumaon Himalayas has been carried out based on photogeological and field studies compiled with data from official published map [11]. Runoff and sediment yield from Giri and Bata River catchments in Himachal Pradesh has been based on physiography, land use, soil, agriculture, forest and wildlife, animal husbandry, hydrology, socio-economic structure of people and various resource degradation problems [12].

A potential groundwater prospecting zones in the Bata River catchment area was obtained by overlapping thematic layers of geology, geomorphology, land use / land cover, soil and drainage in the study area using the index overlay method. In this study, the slope map was created from the digital elevation model created from the $20 \mathrm{~m}$ range contour map of the study area. The ranking was given for each parameter taking into account the importance of each of the thematic layers for groundwater prospecting and the weights were given based on the importance of each feature [13].

The hydrogeomorphic properties of the rocky terrain of the Sironj region of the Vidisha district of Madhya Pradesh in India were studied using IRS-LISS II data. In this study, an attempt was made to use an integrated remote sensing and GIS approach to select suitable locations for groundwater recharge in a hard rock area using recharge basins or reservoirs [14].

The various thematic layers such as geology, linearity density, soil, slope, land use / land cover and drainage density were created for the assessment of groundwater enrichment potential in the upper catchment area of Betwa, Raisen District, Madhya Pradesh, India. Information from the Geological Survey of India was used to create the geological thematic map for this study. The slope map was generated from the digital elevation model to get the slope. LANDSAT-8 OLI data was used for land cover and land use mapping. The parameters of the thematic maps were weighted according to the relative influence of each parameter on groundwater recharge. The results obtained were validated by recording specific yield and groundwater level data from selected wells in potential groundwater recharge areas, which were delineated using GPS positions [15].

A GIS-based multi-criteria decision-making tool was used to assess potential groundwater areas as a predictive tool in the Batman-Hasankeyf sub-basin of Tigris, Turkey. Several hydrological and hydrogeological criteria such as geomorphology, geology, rainfall, drainage density, slope, lineament density, land use and soil properties were taken into account as influencing factors. The weights of the above criteria were determined by the hierarchical process analytical method, and this study confirmed that the specific hydrological and meteorological criteria affecting groundwater and their weights may change depending on the conditions of each region [16].

GIS-based weighted overlap analyzes were used to integrate different thematic layers such as geology, 
geomorphology, soil, linearment density, drainage density, rainfall and land use map created with IRS-ID LISS III satellite images to identify areas of groundwater potential in the coastal part of the Arani and Koratalai watershed in southern India. The groundwater potential map created was superimposed on the groundwater level and the location of the drilling fields for validation [17].

An integrated concept of remote sensing and GIS and analytical hierarchy process (AHP) was used to identify potential groundwater areas (GWPZ) in the Shatt Al-Arab basin. The presence of groundwater and movement control parameters such as lithology, precipitation, geomorphology, slope, drainage density, soil, land use / land use, river distance and lineament density were processed and converted into raster data using the ArcGIS software by assigning proportional weights to them considering the importance of groundwater prospecting [18].

Thematic layers such as lithology, landform, lineament, land use, drainage density, weathering zone thickness, fracture zone thickness, hydrological soils and well yield were developed using IRS-1C satellite data and integrated into a GIS environment using conventional methods to develop groundwater resources in the rocky soils of the Kallar Basin in the districts of Salem and Tiruchirapalli, Tamil Nadu, India. The exact type of artificial recharging system like Check dam, Nallabund, Gully Plugging and Percolation pond, suitable for groundwater supplementation, was identified by overlaying a map of the drainage network with a map of the artificial recharge area [19].

Landsat images were used for land use / land cover mapping and lineament analysis for groundwater prospecting The DEM was used to extract the drainage network, the slope and the geomorphological analysis. Thematic maps were created, analyzed with respect to hydrogeological significance, reclassified by integration and validated using existing data on groundwater yield [20].

The main objectives of this study are a) To determine the areas of groundwater potential in the Giri catchment area; b) Analysis of the suitability of groundwater for human consumption.

\subsection{Study Area}

The investigation area is lying between 30025 to $31016 \mathrm{~N}$ latitude and 77002 to $77044 \mathrm{E}$ longitude and extends over approx. $2632.3 \mathrm{~km} 2$ in the districts of Sirmur, Splan and Shimla of Himachal Pradesh [Figure 1]. It is bounded by the catchment areas of the Sutlej River in the northwest, Tons and Yamuna in the northeast and Ghaggar in the southwest [21].

\subsection{Physiography}

A larger part of the Giri catchment area, found in the central Himalayas and Siwaliks, is hilly with narrow, deep valleys separated by spurs and ridges [22]. The height of the track varies from $438 \mathrm{~m}$ to Rampur Ghat; the mouth of the Giri river at 3,358 $\mathrm{m}$ at Kupar Tibbaon Kupar Dhar separates the catchment areas of the Giri and Tons rivers. 64 percent of the Giri catchment area falls below an altitude of between 1,500 and $3,000 \mathrm{~m}$. The area under the hills of medium height ranges from 1,000 to $1,500 \mathrm{~m}$ and the hills of lower altitudes below $1,000 \mathrm{~m}$ are each 30 to 5 percent. Almost the entire catchment area lies under steep to very steep slopes [Figure 2].

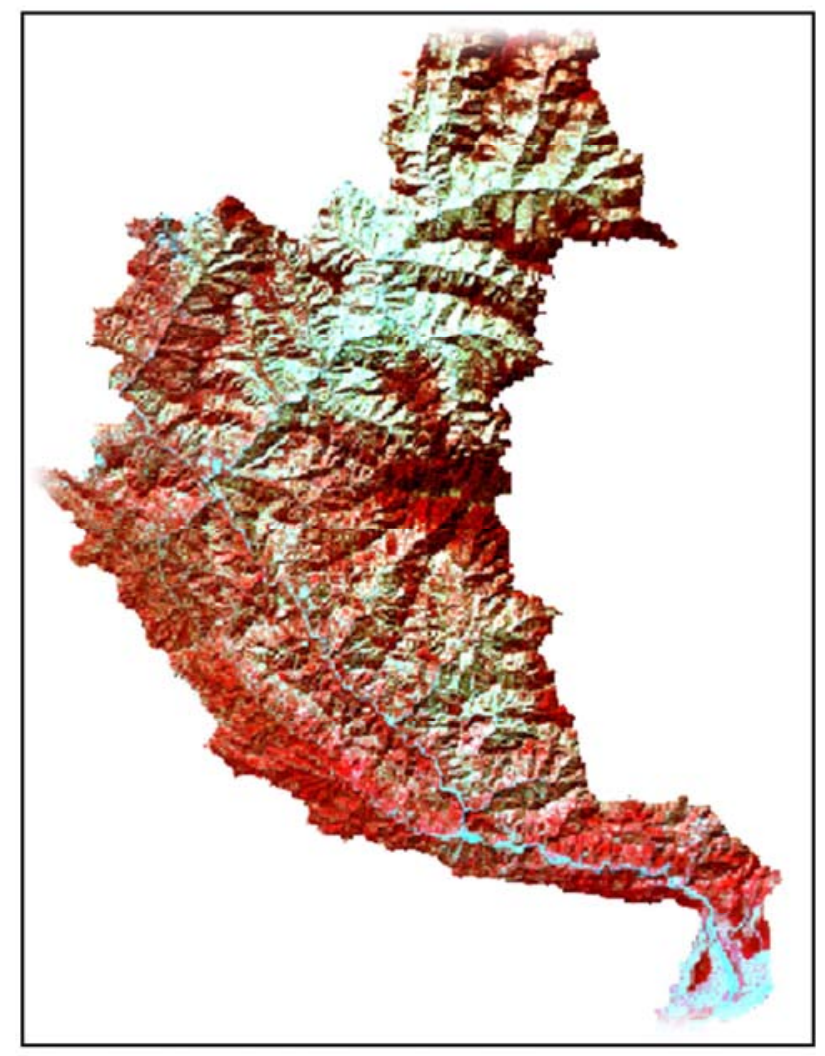

Figure 1. Study Area.

Table 1. Geomorphology Classification.

\begin{tabular}{lll}
\hline Category & \% of Slope & Weight \\
\hline Nearly Level & $<1$ & 7 \\
Very Gentle & $<3$ & 6 \\
Gentle & $<4$ & 5 \\
Moderate Slope & $<10$ & 4 \\
Steep Slope & $<15$ & 3 \\
Moderately Steep to Steep Slope & $<35$ & 2 \\
Very Steep & $>35$ & 1 \\
\hline
\end{tabular}

\subsection{Drainage}

The drainage patter is generally sub diacritics in the Giri river catchment. The catchment is divided in to $36 \mathrm{sub}$ water sheds. The catchment in the North- West is separated from the Sutlej watershed by the Narkanda-Kufir ridge. The ridge gives rise further to the Ginta Dhaman and Nago dhars in the southerly direction. In the North-Eastern part, the Chambi dhar running from NE to NW from a dividing line between the Padar-Tons and Giri watersheds. The main branches of Chambi dhar are the Udi dhar, the Nair-Agra dhar, Gowali dhar, the Kala munda dhar and Thunal-ki-dhar. The Hatu dhar, originating at Hatu peak near Narkanda runs almost parallel to Chambi dhar and continues as chawantru dhar in the south. The eastern boundary of the catchment is found by the mountain ranges emerging 
from the Choor peak $(3,647 \mathrm{~m})$. The Choor peak consulting the highest summit is the nerve centre of many inter-linked

mountain ranges into different direction.

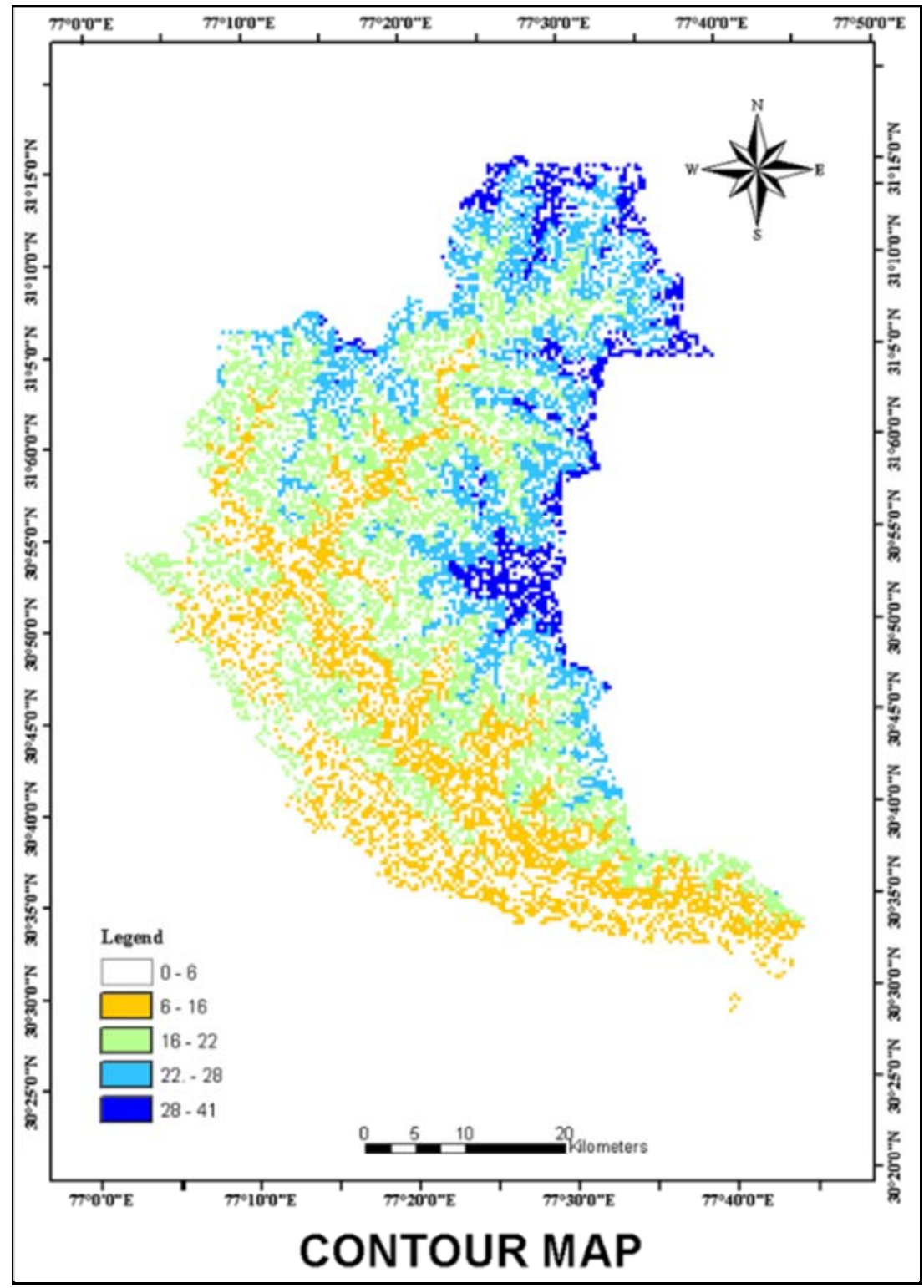

Figure 2. Contour (Slope) map of the study area.

These mountain ranges comprise some of the difficult and rugged trans-Giri area. From the top one can have view of far distant gangetic plain and Sutlej river towards south, the magnificent snowy mountains of Babrinath and Tibet towards north and hills of Shimla on west. The Choor, crown of Sirmaur, is visible from its almost every part. The Jadol dhar after turning northwest from a peak of $2753 \mathrm{~m}$ is called as Kuftu ki dhar. Kuftu ki dhar further branches off at a peak of 2,688 $\mathrm{m}$ into Painkufer dhar and Jajon dhar. The Painkufer dhar ends in Giri river while Jajon dhar again bifurcates into Lojla dhar and Manal dhar further branches off at a peak of 2,026m above Maghaon into Knthial ki dhar and Kuru dhar emerge a number of parallel dhars, namely, Sen ki dhar, Cheon dhar, Gusan dhar, Basali dhar, Kuriya karang dhar and Garol ki dhar etc. ending in Nait ka khala. The Kheri ki dhar etc, ending in Nait ka Khala.

The Kheri ki dhar branches off into Chuwa dhar above Pab village at the peak of $2,088 \mathrm{~m}$ which after running through Rajgarth, Jagas and dudham merges into Giri near Yaswant Nagar. The other dhars originating from Topi dhar are Ber ki dhar merging in Bajhethi ka khala, Bathau dhar terminingg in Pervi khad near Koti, Jhimmi dhar ending in Bajihetu ka khala and Banali dhar. The banali dhar further bifurcate at the peak of 2,325 m into Palu dhar merging into Pervi and Naun dhar split into shivpur dhar, Deothi dhar, Ranaghat dhar and Dhaya-Piti dhars ending in Giri and Pervi. The Aini dhar running to the south of Choor peak splits into Kufta dhar and Kanog ki dhar near Talangana village. Kufta dhar is also known as Haripur dhar upto Haripur fort, where it again branches off into Laangra dhar and Dungi Bhajai dhar. The latter after running to the south of Haripur branches off into Pilani and Bhajai dhars. The latter after running to the south of Haripur branches off into Pilani and Bhajai dhar. The Pilani knows as Jini dhar beyond Khatna 
split into Kufar dhar and shillai dhar. Another important branch of Dungi Bhagani dhar is Dawali Pab dhar which after running southward meet Giri River.

The north-western part of the catchment is separated from the Sutlet watershed by Dumi-Shimla-Keseru-TaradeviKaithlighat-Solan-Dagshi ridge. The south western part is determined by Dagshai-baulhi Shaya and Saharan Dharti dhar ridges running between Giri and Ganggar watersheds. The Dharti dhar after passing through Prem nagar, naina Tikka, Bhur, Singh, Sarahan, Baghar, Rama, Kansar and Malgi, ends up in Giri River near north of Rajban village. The Sarahan Dharti dhar alone with Sain dhar, another important and independent range, constituents the Cis-Giri area, Sain dhar arises from near the confluence of Kawal and Giri River from Mari keg hat ka khala and Jalal river. The drar ends up at the confluence of Giri and Jalal near Dadahu. Purra ki dhar and Sarera ki dhar emerges from Sain dhar and terminate in Jalal river respectivel. The southern part of the Giri catchment is delimited by Chauri and Kamrahoo-Bharfa dhar, separating it from Bata and Ton River catchments respectively [23, 24].

\subsection{Geomorphology}

The study area could be divided into hills, piedmonts, braided rivers, point bars, sand bars and terraces [25]. Area under highly dissected structural hills with parallel drainage pattern occupies $6.55 \%$ of the study area where as area under highly dissected denudational hills with radial drainage occupies $19.96 \%$ of the study area. Area under highly, moderately and low dissected denudational hills occupies $23.66 \%, 16.21 \%$ and $7.02 \%$ of the study area respectively. Whereas moderately dissected denude structural hills and low dissected structural hills occupy the area of 14.95 and 10.32 respectively. The area under the residual hills, piedmonts, channel bars, point bars and the terrace was $0.17 \%, 0.44 \%$, $0.03 \%, 0.07 \%$ and $0.64 \%$ [Figure 3 ].

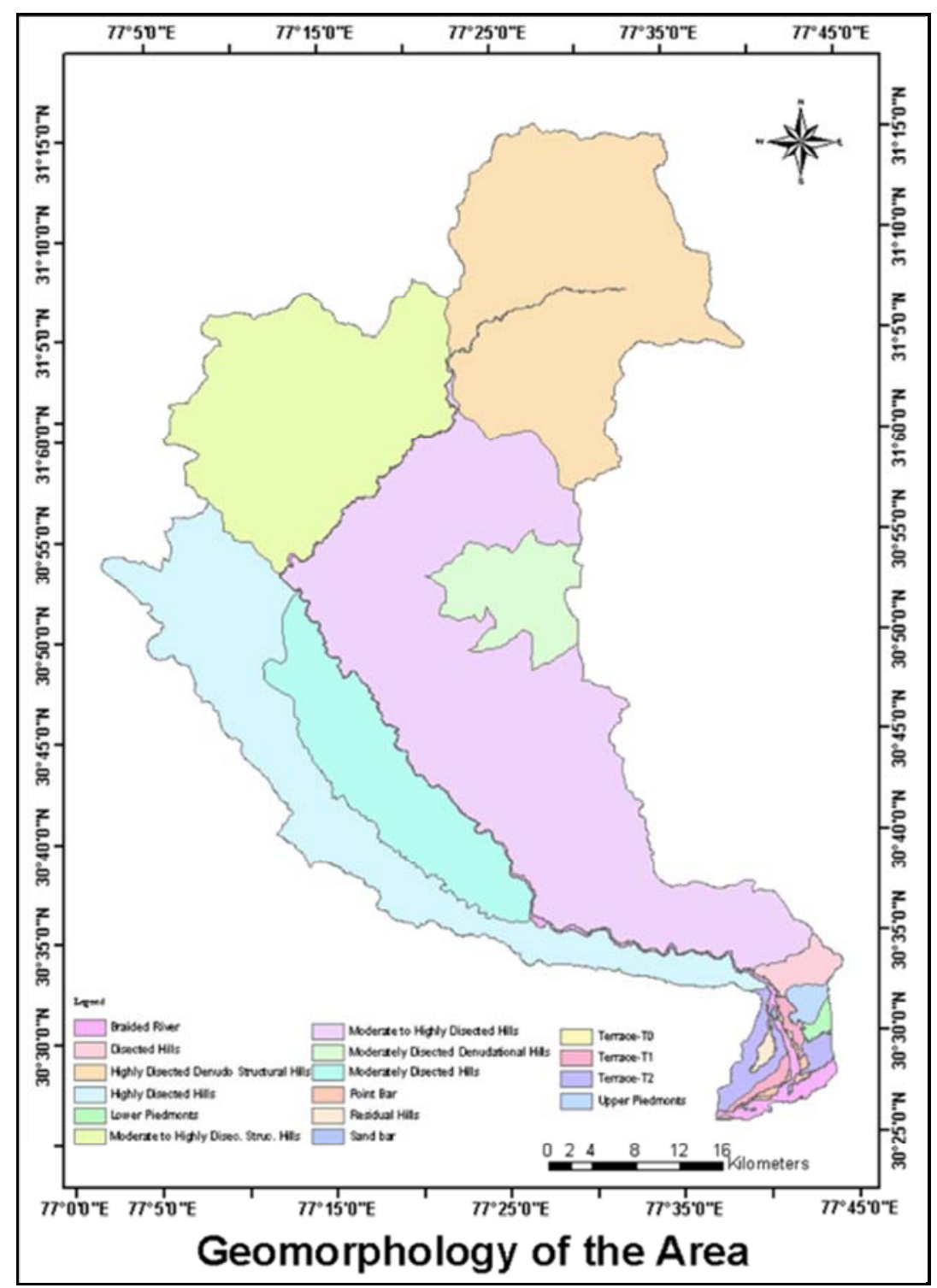

Figure 3. Geomorphology (Land form) of the study area. 
Table 2. Geomorphology Classification.

\begin{tabular}{ll}
\hline Type & Weight \\
\hline Braided River & 8 \\
Mod. disec. denu. struc. hills & 2 \\
High. disec. struc. hills & 1 \\
High. disec. denudo. & \\
struc. hills & 1 \\
High. Disec. Denu. hills & 1 \\
Mod. Disec. Struc. hills & 2 \\
Mod. Disec. Struc. Hills & 2 \\
Low Disec. Struc. Hills & 3 \\
Low Disec Denudo. Struc. Hills & 3 \\
Residual hills & 1 \\
Terraces & 9 \\
Piedmont & 8 \\
Point Bar & 9 \\
\hline
\end{tabular}

\subsection{Geology}

Rock found in the area comprise shales, sandstone, limestone, slate and schist deposited during the period stretching from 1 to over 600 million years ago when it was a vast sea called Tethys. The fluctuation in depth and expense of sea, the variation in nature of sediments brought by feeder channels and physio-chemical conditions of sea water led to the deposition of various groups of sediments having a thickness of several kilometers. The sediments were deposited layer by layer often thinner than millimeters.

The sequence of deposition was seldom, smooth and continuous. The large boulders in Balani Formation indicate complete glaciation all over the sea. The major disturbance was rise of Himalayas by bulking of sediments in the Tethys due to collision of northward floating Indian subcontinent with the Chinese main land. This was followed by a lull of many millions years during which huge sediments were deposited in shallow depressions created by Himalayan uplift. The second mountain building activity led to rise of low Shiwalik ranges. The instability created by the rise of Himalaya and Siwaliks is still observed and the fact that Himalays are still rising. Geographically, the track can be divided into three zones such as sub, outer and middle Himalays zone. Sub-Himalayan zone, the zone representing Siwalik hills and flat to undulating Dun Valley has sediment of tertiary age. It composed chiefly of altering beds of line grained friable sunstone and clay. Large pockets of conglomerate, shale and veins of red marl are also present in the area. These are highly susceptible to erosion by water [22].

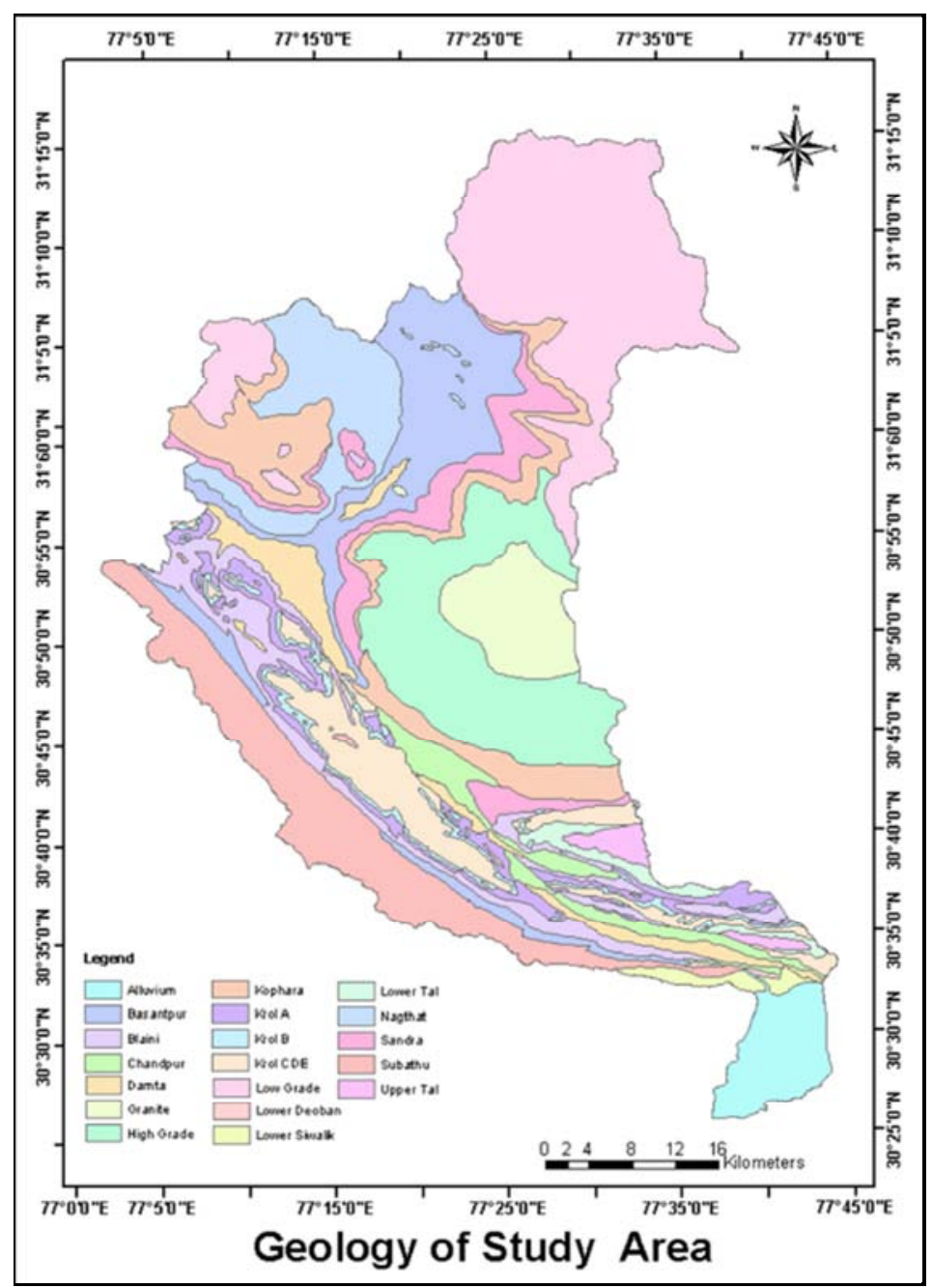

Figure 4. Geological formation of the study area. 
Table 3. Geology Classification.

\begin{tabular}{llll}
\hline Formation & Weight & Formation & Weight \\
\hline Alluvium & 10 & Kroal B & 1 \\
Basantpur & 2 & Krol CDE & 1 \\
Blani & 2 & Lower Deoban & 1 \\
Chandpur & 1 & Lower Siwalik & 2 \\
Damta & 1 & Lower Tal & 1 \\
Granite & 2 & Naghat & 1 \\
High Grade & 2 & Sandra & 1 \\
Kophara & 2 & Upper Tal & 1 \\
Krol A & 1 & Subathu & 2 \\
\hline
\end{tabular}

In Outer Himalays zone, it is mostly confined to South-West Giri with Sain dhar, Dharti and Kumaroo-Bharli in its folds. The strata are similar to Sub-Himalayas, but, the upper layer is of somewhat harder sanstone, the main rocks are sandstone shale and pockets of limestone, clay and conglomerates. The rock formation of the Trans-Giri falling in Middle Himalaya zone emerges out a place completely replacing sandstone. However, the trans Giri, northern and north west part of the tract falls in to Middle Himalayan zone. It is mostly composed of crystalline metamorphic rocks such as granite-gneiss, slate, mica-schist and quartzite with unfossiliferous deposit of ancient origin. The highest ranges up to $5400 \mathrm{~m}$. Granite and gneiss rocks are generally confined to the higher ranges of the tract [Figure 4].

\subsection{Climate}

Climate varies with altitude; it is subtropical sub-humid in the lower part of the route in the Shiwaliks with a humid temperature in the upper part of the central Himalayas. Rainfall in the basin varies from $824 \mathrm{~mm}$ in Kotkhai to 1,933 $\mathrm{mm}$ in Sarahan. The average rainfall of the Catment is 1,287 $\mathrm{mm}$. Most of the precipitation falls in the monsoon season from June to September. Winter rains occur from December to March. Snowfall is normal in areas above $1,800 \mathrm{~m}$. Drought occurs both in the pre- and post-monsoons. March, April, May, October and November are generally dry months [Figure 5]. The region has the district seasons of summer (April-June), monsoons (July-September), autumn (October-November) and winter (December-March). Summers are hot in the Siwaliks, with temperatures around $420^{\circ} \mathrm{C}$, while winters are cool. Table 1 shows the precipitation data around the Giri Basin [26].

\section{Annual Rain Fall in the Study Area}
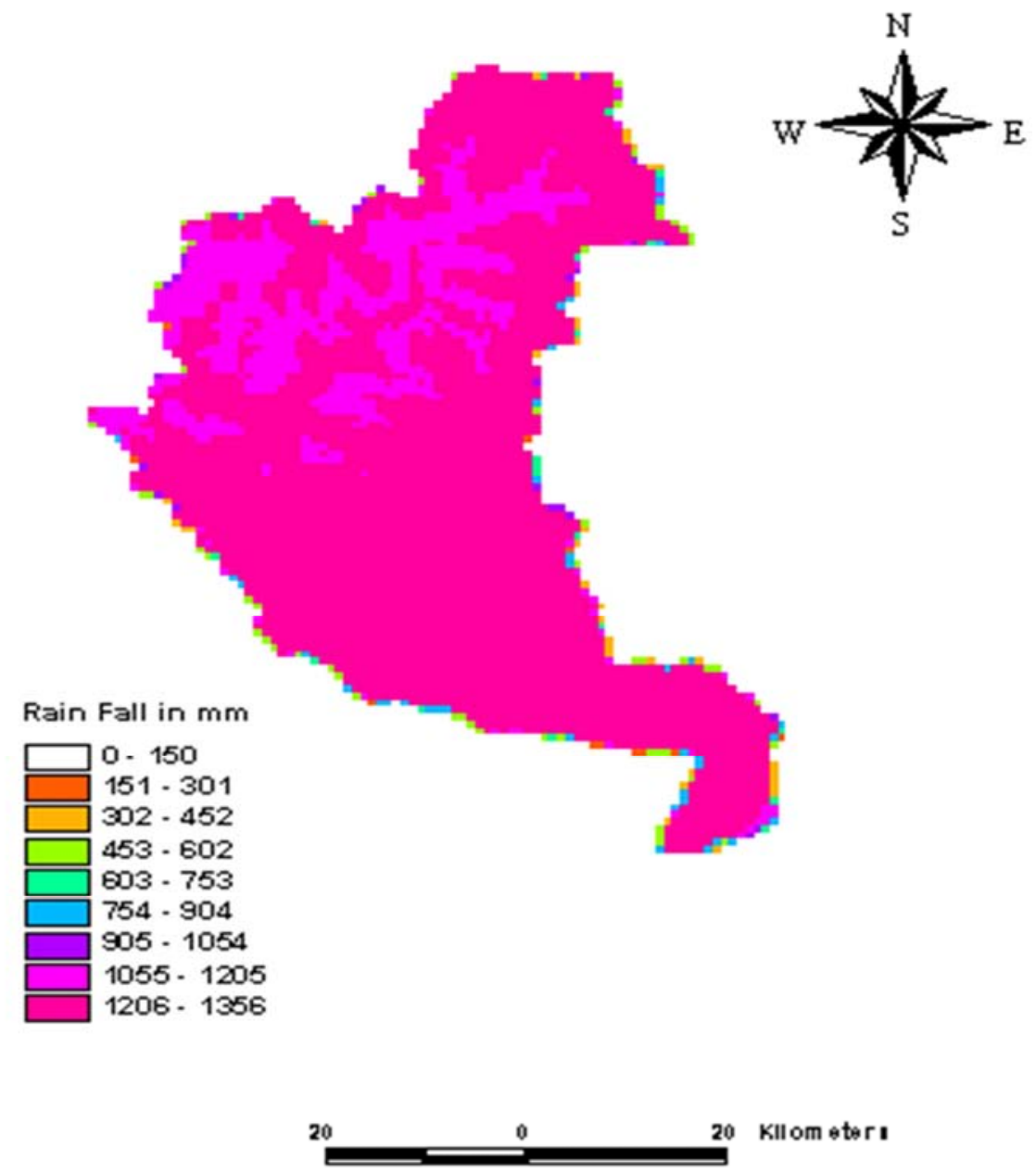

Figure 5. Annual Precipitation map of the study area. 
Table 4. Rainfall Classification.

\begin{tabular}{ll}
\hline Level & Weight \\
\hline Low & 1 \\
Moderate & 2 \\
High & 3 \\
\hline
\end{tabular}

\subsection{Data Used in the Study}

Satellite imagery of IRS LISS III FCC and PAN as well as
Landsat 7 TM FCC and PAN imagery, SRTM-DEM data, aerial imagery and topographical sheets from Survey of India, geological map of Rupke, precipitation data from regional research station Himachal Pradesh Krishi Visvavidyalaya, Dheulakunan and the data downloaded from Barkly University [Table 5] were also used to create the various thematic maps such as geology, geomorphology, structure and lineament, drainage density, slope and aspect.

Table 5. Data Used in the Study.

\begin{tabular}{lll}
\hline Type of Data & Details of the Data & Source of data \\
\hline Survey of India (SOI) Topo sheets & $53 \mathrm{E} / 4,53 \mathrm{E} / 8,53 \mathrm{~F} / 1,53 \mathrm{~F} / 2,53 \mathrm{~F} / 3,53 \mathrm{~F} / 10$, & \\
Aerial Photographs & $53 \mathrm{~F} / 11(\mathrm{Scale} 1: 50,000)$ & Survey of India (SOI), Dehradun \\
Geology map & (Scale $1: 25,000)$ & \\
& Scale $1 / 4$ inch to the mile & J. Rupke and Collaborators \\
Rain fall data & Monthly & Regional Research Station, Himachal Pradesh Krisi \\
& rain & Visvavidyalaya, Dheulakuan, Sirmour, H. P, Barkley University \\
Satellite Images & & \\
1. IRS-IC & LISS III FCC, PANFCC, PAN & NRSA, Hyderabad \\
2. LANDSAT 7 ETM & & USGS \\
\hline
\end{tabular}

\section{Methodology}

The study was conducted in three phases and the following methodologies were used for the study:

\subsection{First Stage}

1. Demarcation of the lithological boundaries, structure and the geomorphological features from the aerial photographs on a scale of 1: 25,000 by means of stereoscopic analysis.

2. The analog maps received from various organizations

3. were scanned and converted to digital format by manual digitization in the ERDAS environment

4. The Giri watershed was outlined on the mosaic

5. topographical sheets and the area of interest was subdivided in the study area.

6. Before the field work, aerial photographs and satellite

7. data were interpreted based on visual interpretations. Image enhancement was performed prior to visual interpretations. The lithological boundaries, as well as the main geomorphic units, were delineated based on the difference in the dissection pattern and the variation of the tone to generate thematic layers such as geology, geomorphology, lineament and structure, etc.

8. These interpreted data were mapped onto a 1: 50,000

9. scale base map and a hydrogeomorphological map was prepared prior to the field investigations.

\subsection{Second Stage}

In order to verify accuracy of pre-field generated maps on various theme, two weeks' field investigation was carried out along selected traverses. During this period ground truth data and ground water sample were collected in respect to generated thematic maps. In the same time ground water samples were analyzed in the field to delineate the suitable locations for groundwater extraction for human consumption.

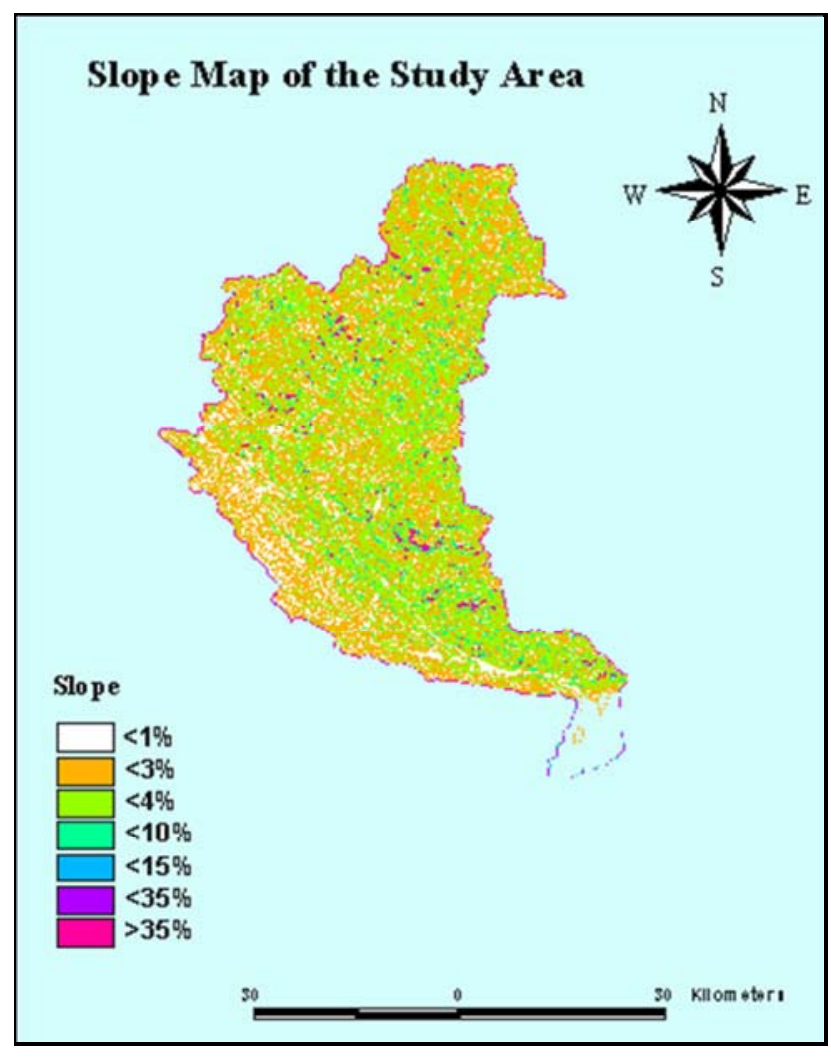

Figure 6. Slope Map of the Study Area

\subsection{Third Stage}

This is the final phase of the study, based on the ground truth information gathered during the field visit, the thematic maps have been modified and reinterpreted accordingly. In order to delimit the ground water potential in the study area, the various thematic maps were integrated into the GIS environment with 
the aid of the Weighted Index Overlay Analysis (WIOA). This is a simple and straightforward method for a combined analysis of multiclass maps. The effectiveness of this method lies in the fact that human judgment can be incorporated into the analysis. A weighting represents the relative importance of a parameter to the goal. The WIOA method takes into account the relative importance of the parameters and the classes that belong to each parameter. There is no standard scale for a simple weighted stacking method. To this end, analysis criteria are defined and importance is attached to each parameter. The determination of the weight of each class is very important in the integrated analysis, since the result depends very much on the assignment of an appropriate weight

\section{Results}

The presence of groundwater depends on the conditions of the subsurface; this requires a very complex analysis and yet the properties of the subsoil are fundamentally determined by geology and morphology. Therefore, it is necessary to integrate various surface and groundwater features in order to gain a comprehensive understanding of an area's groundwater prospects. In order to determine the potential groundwater exploration areas, the various thematic maps were integrated into the GIS environment. The index overlay method is one of the best hydro geomorphic integration methods for delimiting potential groundwater prospecting areas.

The slope is very important for recharge and occurrence of groundwater for a particular area. If the slope is steeper, the drain will be larger and the infiltration will be very low. The Slope map was created from the DEM of the area and taking into account given the ranking 9 and different weights were assigned to the different classes of slope [Figure 6]. In this study Aspect also considered as an important parameter for ground water occurrence and recharge. Southward direction sloping is more influence for groundwater occurrence compare with northward direction sloping since it exposes more time to solar radiation.

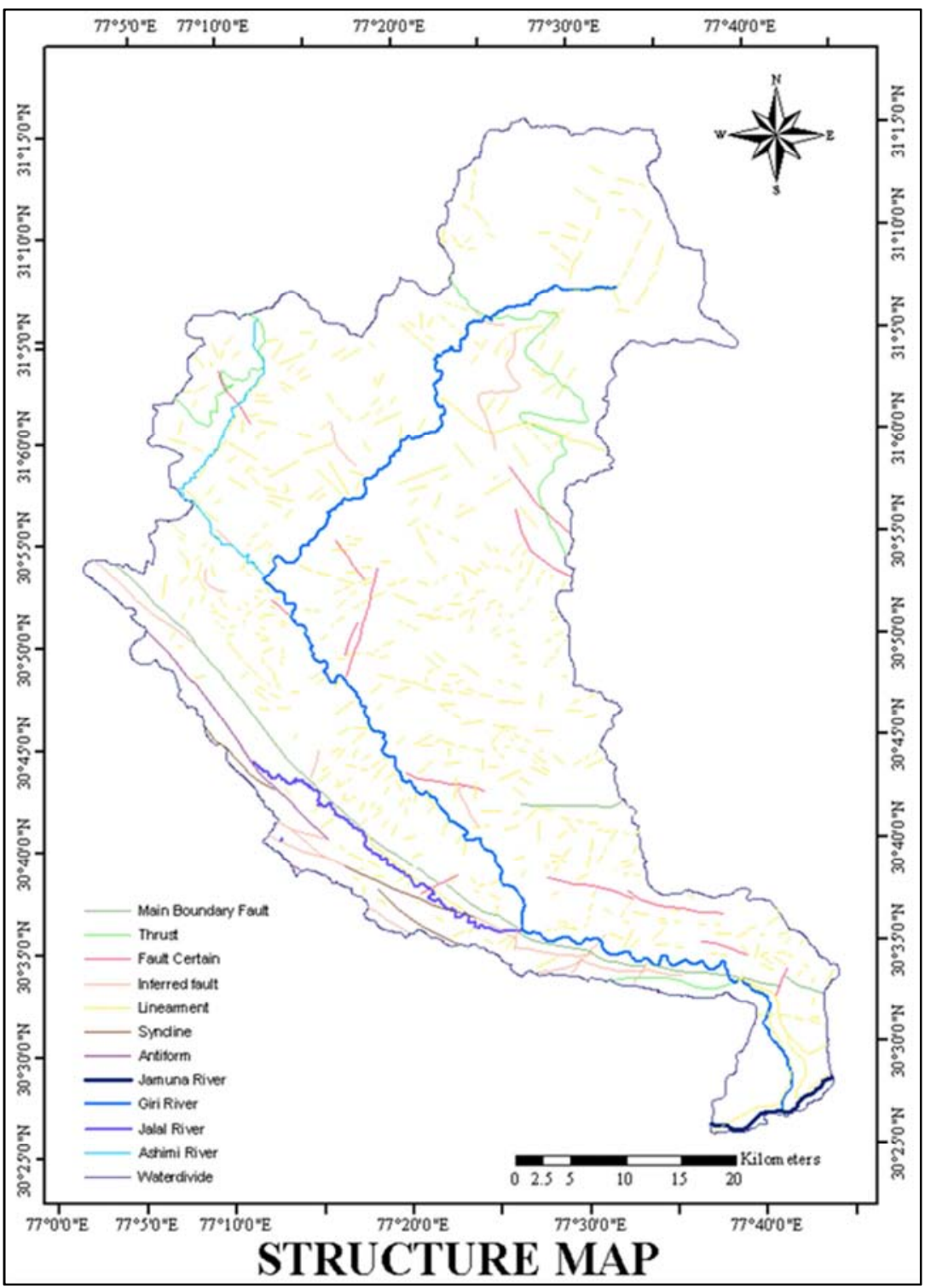

Figure 7. Lineament (Structure) map of the study ar. 
Table 6. Aspect Direction.

\begin{tabular}{ll}
\hline Aspect (6) & \\
\hline Flat & 9 \\
North & 1 \\
North East & 2 \\
South & 6 \\
South East & 6 \\
South West & 4 \\
West & 4 \\
East & 4 \\
North West & 3 \\
\hline
\end{tabular}

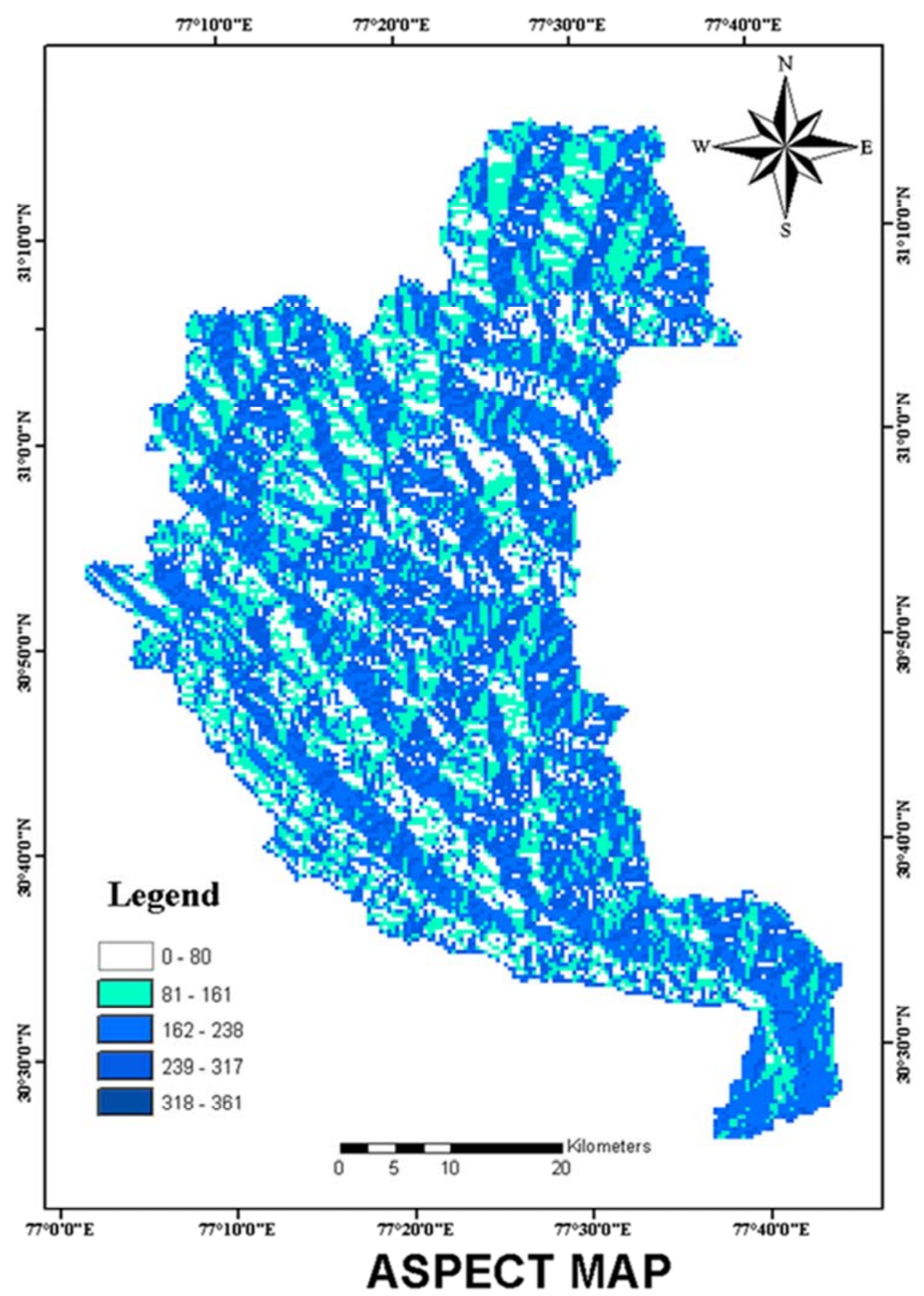

Figure 8. Aspect direction map of the study area. 
Table 7. Water Quality Parameters Used in the Study

\begin{tabular}{|c|c|c|c|c|c|c|}
\hline Sample No. & Parameters (mg/l) & Neruwala & Manpurdura dugwell & Sippur & Bangaran & Borrativala \\
\hline & $\mathrm{pH}$ & 8 & 8 & 8 & 8 & 8 \\
\hline & Temperature $\left({ }^{\circ} \mathrm{C}\right)$ & 24 & 24 & 19 & 19 & 25 \\
\hline & Coliform & Nil & Nil & Nil & Nil & Nil \\
\hline & Fluoride & 0.6 & 1.5 & 0.6 & 0.6 & 0.6 \\
\hline & Dissolved Oxygen & 8 & 7.6 & 2.6 & 3.4 & 3.8 \\
\hline & Residual Chloride & 0.2 & 0.2 & 0.2 & 0.2 & 0.2 \\
\hline & Phosphorous & 0.1 & 0.1 & 0.1 & 0.1 & 0.1 \\
\hline & Nitrate as Nitrate & 10 & 10 & 10 & 45 & 10 \\
\hline & Iron & 0.6 & 0.6 & 3.0 & 0.6 & 3.0 \\
\hline & Hardness & 380 & 380 & 180 & 164 & 312 \\
\hline & Chloride & 24.82 & 24.82 & 42.54 & 42.54 & 40 \\
\hline & Ammonia & 1.0 & 1.0 & 1.0 & 1.0 & 1.0 \\
\hline & Turbidity (NTU) & 10 & 200 & 100 & 10 & 10 \\
\hline \multirow[t]{14}{*}{ Sample No. } & Parameters (mg/l) & Rajpur & Sinpur & Mastharali & Khorowala & Manpurdura \\
\hline & pH & 8 & 8 & 8 & 8 & 7 \\
\hline & Temperature $\left({ }^{0} \mathrm{C}\right)$ & 23 & 25 & 25 & 25 & 25 \\
\hline & Coliform & Nil & Nil & Nil & Nil & Nil \\
\hline & Fluoride & 0.6 & 1.5 & 1,5 & 1.5 & 1.5 \\
\hline & Dissolved Oxygen & 2 & 10.8 & 4.6 & 3.6 & 0.18 \\
\hline & Residual Chloride & 0.2 & 0.2 & 0.2 & 0.2 & 0.2 \\
\hline & Phosphorous & 0.1 & 0.1 & 0.1 & 0.1 & 0.1 \\
\hline & Nitrate as Nitrate & 45 & 10 & 45 & 10 & 10 \\
\hline & Iron & 3.0 & 3.0 & 1.5 & 0.3 & 3.0 \\
\hline & Hardness & 316 & 400 & 400 & 440 & 224 \\
\hline & Chloride & 0.16 & 53.18 & 63.81 & 35.45 & 53.16 \\
\hline & Ammonia & 1.0 & 1.0 & 1.0 & 1.0 & 1.0 \\
\hline & Turbidity (NTU) & 50 & 10 & 10 & 10 & 10 \\
\hline
\end{tabular}

\begin{tabular}{|c|c|c|c|c|c|c|c|c|}
\hline Sample No. & Bhagani & Rampur & Puruwala & Nawada & Yamuna River & Giri River & Aawini River & Jalal River \\
\hline & 8 & 8 & 8 & 7 & 8 & 8 & 8 & 8 \\
\hline & 25 & 25 & 26 & 25 & 23.5 & 21 & 17 & 23 \\
\hline & Nil & Nil & Nil & Nil & Nil & Nil & Nil & Nil \\
\hline & 1.5 & 1.5 & 1.5 & 1.5 & 1.5 & 1.5 & 1.5 & 0.6 \\
\hline & 7.2 & 5.2 & 0.28 & 5.6 & 14 & 9 & 13 & 7.5 \\
\hline & 0.2 & 0.2 & 0.2 & 0.2 & 0.2 & 0.2 & 0.2 & 0.2 \\
\hline & 0.1 & 0.1 & 0.1 & 0.1 & 0.1 & 0.1 & 0.1 & 0.1 \\
\hline & 45 & 10 & 10 & 45 & 10 & 10 & 10 & 10 \\
\hline & 1.0 & 0.3 & 0.3 & 3.0 & 0.3 & 0.3 & 0.3 & 0.6 \\
\hline & 260 & 200 & 256 & 180 & 200 & 220 & 200 & 176 \\
\hline & 53.45 & 35.45 & 35.45 & 35.45 & 35.45 & 35.45 & 17.72 & 26 \\
\hline & 1.0 & 1.0 & 1.0 & 1.0 & 1.0 & 1.0 & 1.0 & 1.0 \\
\hline & 10 & 10 & 10 & 10 & 10 & 10 & 10 & 10 \\
\hline
\end{tabular}

Ranking the lineament as 7 and equal weightages given for all lineaments [Figure 7]. The drainage density is also a very significant parameter for the occurrence and recharge of groundwater. In rocky terrain, the drainage density is very high and infiltration is very low. Hence the classification of the drainage density as 7 and the different weightages were given for the different drainage density classes

Rank 6 given for the aspect [Figure 8] and different weights for different directions [Table 6]. The annual precipitation is also a very important factor for the presence of groundwater and given the ranking 6 also for rain fall and given weightages for different rainfall level

Geomorphology is also a very significant parameter for groundwater occurrence and recharge. Ranking 8 was given for the geomorphology and different weightages were given for different morphological structures [Table 2]. Permeability and porosity control the groundwater occurrence and recharge potential and it depends on the lithology of the area. Ranking 8 was given for geology and different weightages were given for different rock types [Table 3]. Primary porosities are almost zero in hard rock, which is why the lineaments are very important for the occurrence and recharge of groundwater.

Final hydrogeomorphological map indicates very high groundwater potential (3.6\%) in river terraces, lower piedmont, Sand bars, Point bars and braided river areas as well as highly fractured areas and alluvial plain. Highly dissected structural hill areas showed very poor groundwater potential (3.2\%). Moderate to lower dissected structural hill areas indicated moderate to lower groundwater potential (52.24\%). Along the braided river indicated very high ground water potential. Although, the annual rainfall in the watershed is relatively moderate $(1287 \mathrm{~mm})$, the availability of groundwater is problematic because of low recharge potential, high runoff mainly due to hard rock terrain, excessive 
withdrawal of groundwater for irrigation purposes have caused continuous lowering of the groundwater table over the years [Figure 9].

\section{Hydrogeomorphology of the Study Area}

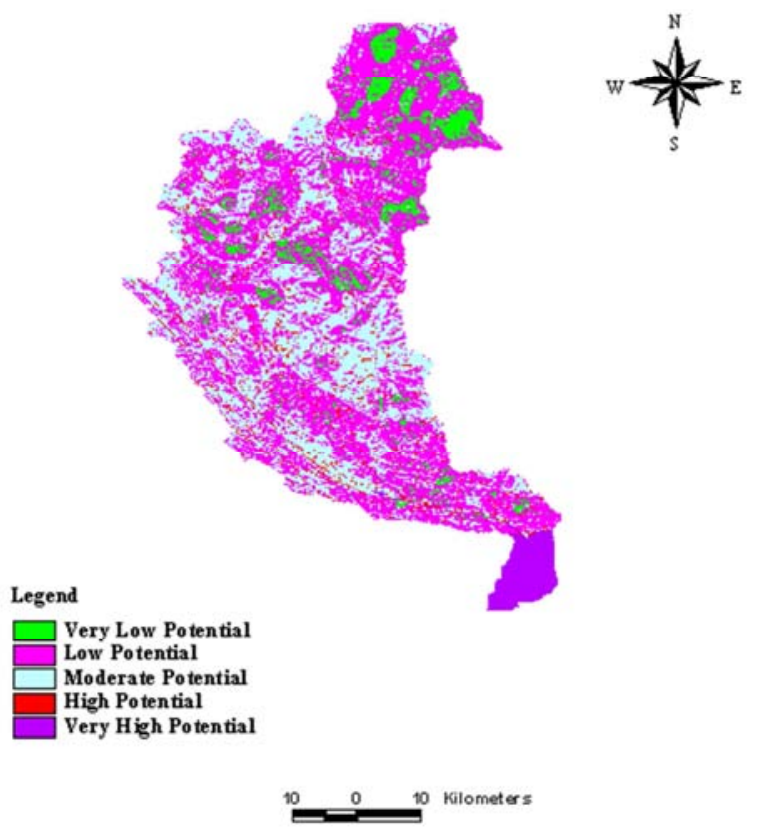

Figure 9. Hydrogeomorphology map of the study area.

No groundwater study is complete without a known groundwater quality and its suitability for various purposes. The composition of groundwater largely depends on the nature of the rock formations, the physiography and soil environment, and the recharge and draft conditions under which it occurs.

Groundwater behaves like one of the best solvents with its long association under different climatic conditions to break up the rock formations to bring all soluble products into solution. Groundwater quality plays an important role in promoting both the standard of agricultural production and human health. When the water quality deteriorates, it naturally affects the soil-crop-water system and thus human health. In the early stages of water quality deterioration, the damage may be minor, but if not examined at the right time, this water is not suitable for any purpose. Human activities such as industrialization, mining, and urbanization can also generate effluent that pollutes the environment. During the field work, 30 groundwater samples were collected from the working dug well, the dug-kum borehole, the bore wells and the river water in the study area. The sample was analyzed in the field for 13 water quality parameters using a field test kit. The analyzed parameters are listed in Table 7 with the permissible standard limits.

Most of the analyzed water samples of study area were in standard permissible limits. Iron content was very high in few places and this may be due o various reason probably due to iron casing of the tube well and another reason is iron rich rock and soil may be contaminated with groundwater therefore further studies on lithology is the study area is necessary for clarifications.

\section{Conclusion}

The study shows the importance of remote sensing technology, which is an information tool that provides sufficiently accurate and complete spectral, spatial and temporal information of the earth's surface. Furthermore, this study confirmed the effectiveness of GIS, which can store and manipulate RS data and other special, non-spatial data very efficiently.

Overlay analysis was used in the creation of hydrogeomorphological maps, which is a simple and straightforward method for the combined analysis of multi-class maps. The effectiveness of this method lies in the fact that human judgment can be incorporated into the analysis. The analysis criteria are defined and a ranking is assigned to each parameter. Determining the weighting of each class is very important in the integrated analysis, as the result largely depends on the assignment of an appropriate weighting.

Hydrogeomorphological map indicates very high groundwater potential in river terraces, Lower piedmont, Sand bar, Point bars and Braided river areas, highly fractured areas and alluvium plains. Area covering highly dissected structural hill indicated very poor groundwater potential Moderate to lower dissected structural hill areas indicate moderate to low groundwater potential. Along the braided river indicated very high groundwater potential. Rainwater harvesting or any other artificial recharge method is best suited to improve groundwater potential in low-potential areas. Artificial recharge is the process of increasing the natural movement of surface water in underground formations through certain artificial methods. This is achieved by creating infiltration systems or by inducing a recharge of surface water. In hard rock areas, the underlying lithological units may not have sufficient porosity and permeability.

In these areas, the groundwater recharge extends below the water withdrawn from the aquifers. This means that the groundwater cannot meet the needs of agriculture or drinking purpose. This means that additional replenishment through artificial methods is required to fill the water deficit. In India, artificial recharge measurements are carried out in large areas of hard rock, mainly in Maharashta and southern India. The performance of these efforts can be greatly enhanced when carried out through proper scientific planning. Integrated remote sensing and GIS can be a very powerful tool for planning the adequacy of artificial charging facilities. However, this powerful tool has yet to be widely used in India for this purpose.

All water samples analyzed in the study area were within the allowable standard range. The iron content was very high in some places and this can have various reasons, probably due to the iron casing of the tube well another reason groundwater may contaminate with iron rich rock and soil in the particular area. Lithological study is necessary for problematic area to taken into conclusion. Analyzed data 
show that hardness of most of water samples were very high but in the permissible limit. Solar still is one of the best methods for treatment of this hard water for human consumption.

\section{Acknowledgements}

The author thanks the Indian Institute of Remote Sensing, Dehradun, India for providing the resources and laboratory facilities necessary to make this research successful, and all others who have helped in various ways during this research.

\section{References}

[1] Saraf, A., Choudhary, P., Sarma, B. and Ghosh, P., 2001. Impacts of reservoirs on groundwater and vegetation: A study based on remote sensing and GIS techniques. International Journal of Remote Sensing, 22 (13), pp. 2439-2448.

[2] Thakur, J., Singh, S. and Ekanthalu, V., 2016. Integrating remote sensing, geographic information systems and global positioning system techniques with hydrological modeling. Applied Water Science, 7 (4), pp. 1595-1608.

[3] Prasad, H., Bhalla, P. and Palria, S., 2014. Site Suitability Analysis of Water Harvesting Structures Using Remote Sensing and GIS - A Case Study of Pisangan Watershed, Ajmer District, Rajasthan. The International Archives of the Photogrammetry, Remote Sensing and Spatial Information Sciences, XL-8, pp. 1471-1482.

[4] Breunig, M., Bradley, P., Jahn, M., Kuper, P., Mazroob, N., Rösch, N., Al-Doori, M., Stefanakis, E. and Jadidi, M., 2020. Geospatial Data Management Research: Progress and Future Directions. ISPRS International Journal of Geo-Information, 9 (2), pp. 1-20.

[5] Venkateswarlu, G., Jayasankar, G. and Saradhi, B., 2014. Impact Assessment of Land Use Change on Ground Water Quality Using Remote Sensing \& GIS for Zone V under Municipal Corporation Hyderabad. IOSR Journal of Mechanical and Civil Engineering, 11 (1), pp. 36-42.

[6] Prasad, R., Mondal, N., Banerjee, P., Nandakumar, M. and Singh, V., 2007. Deciphering potential groundwater zone in hard rock through the application of GIS. Environmental Geology, 55 (3), pp. 467-475.

[7] Teixeira, J., Chaminé, H., Carvalho, J., Pérez-Alberti, A. and Rocha, F., 2013. Hydrogeomorphological mapping as a tool in groundwater exploration. Journal of Maps, 9 (2), pp. 263-273.

[8] Mark Settle, James V. Taranik, 1983. Current Research in Geological Applications of Remote Sensing Techniques and Implications for Petroleum Geology: ABSTRACT. AAPG Bulletin, 67 (3), pp. 546-547.

[9] Das, S., 2017. Delineation of groundwater potential zone in hard rock terrain in Gangajalghati block, Bankura district, India using remote sensing and GIS techniques. Modeling Earth Systems and Environment, 3 (4), pp. 1589-1599.

[10] Holland, M., 2012. Evaluation of factors influencing transmissivity in fractured hard-rock aquifers of the Limpopo Province. International Conference on Groundwater Special
Edition 38 (3), pp 379-390.

[11] Rupke, J., 1974. Stratigraphic and structural evolution of the Kumaon Lesser Himalaya. Sedimentary Geology, 11 (2-4), pp. 81-265.

[12] Rupke, J., 1991. Geological Maps, Their Solution and Interpretation. Sedimentary Geology, 70 (1), pp. 84.

[13] Kuruppath, N. and Kannan, B., 2017. Identification of Potential Groundwater Recharge Zones Using Remote Sensing and Geographical Information System in Amaravathy Basin. Journal of Remote Sensing \& GIS, 06 (04). pp 1-10.

[14] Saraf, A. and Choudhury, P., 1998. Integrated remote sensing and GIS for groundwater exploration and identification of artificial recharge sites. International Journal of Remote Sensing, 19 (10), pp. 1825-1841.

[15] Ahirwar, S., Malik, M., Ahirwar, R. and Shukla, J., 2020. Application of Remote Sensing and GIS for Groundwater Recharge Potential Zone Mapping in Upper Betwa Watershed. Journal of the Geological Society of India, 95 (3), pp. 308-314.

[16] Çelik, R., 2019. Evaluation of Groundwater Potential by GIS-Based Multicriteria Decision Making as a Spatial Prediction Tool: Case Study in the Tigris River Batman-Hasankeyf Sub-Basin, Turkey. Water, 11 (12), pp. $1-16$.

[17] Suganthi S, Elango L and Subramanian S. K, 2013, Groundwater potential zonation by Remote Sensing and GIS techniques and its relation to the Groundwater level in the Coastal part of the Arani and Koratalai River Basin, Southern India, Journal of Earth Science Research, 17 (2), pp 87-95.

[18] Allafta, H., Opp, C. and Patra, S, 2020. Identification of Groundwater Potential Zones Using Remote Sensing and GIS Techniques: A Case Study of the Shatt Al-Arab Basin. Remote Sensing, 13 (1), pp 1-28.

[19] Krishnamurthy, J., Mani, A., Jayaraman, V. and Manivel, M., 2000. Groundwater resources development in hard rock terrain - an approach using remote sensing and GIS techniques. International Journal of Applied Earth Observation and Geoinformation, 2 (3-4), pp. 204-215.

[20] Oyedele, A., 2019. Use of remote sensing and GIS techniques for groundwater exploration in the basement complex terrain of Ado-Ekiti, SW Nigeria. Applied Water Science, 9 (3), pp 1-13.

[21] Singh, M., Gupta, B., Das, S., Avasthe, R. and Sarvade, S., 2015. Assessment of Economic Viability of Different Agroforestry Systems in Giri Catchment, Himachal Pradesh. Economic Affairs, 60 (3), pp 557-561.

[22] Pareta K and Pareta U, 2012, Landslide Modeling and Susceptibility Mapping of Giri River Watershed, Himachal Pradesh, International Journal of Science and Technology 1 (2), pp 91-104.

[23] Sharma D. D and Thakur B. R, 2016, Prioritization of Micro Watersheds in Giri Catchment for Conservation and Planning, Transactions of the Institute of Indian Geographers 38 (2), pp. 267-280.

[24] Prakasam, C., R, A., Nagarajan, B. and Kanwar, V, 2020. Site-specific geological and geotechnical investigation of a debris landslide along unstable road cut slopes in the Himalayan region, India. Geomatics, Natural Hazards and Risk, 11 (1), pp. 1827-1848. 
[25] Rautela R and Lakhera R. C, 2000, Landslide risk analysis between Giri and Tons Rivers in Himachal Himalaya (India), International Journal of Applied Earth Observation and Geoinformation 2 (3), pp. 153-160.
[26] J Wani1 J. M, Sarda V. K, Sanjay. K., Assessment of trends and variability of rainfall and temperature for the district of Mandi in Himachal Pradesh, India, Slovak Journal of Civil Engineering, 25 (3), pp 15-22. 